CZASOPISMO INŻYNIERII LĄDOWEJ, ŚRODOWISKA I ARCHITEKTURY JOURNAL OF CIVIL ENGINEERING, ENVIRONMENT AND ARCHITECTURE

JCEEA, t. XXXIII, z. 63 (3/16), lipiec-wrzesień 2016, s. 329-340

\author{
Katarzyna PIETRUCHA-URBANIK ${ }^{1}$ \\ Tatiana CHRY N' ${ }^{2}$
}

\title{
ANALYSIS OF WATER SUPPLY INFRASTRUCTURE STATE IN LUBLIN PROVINCE
}

\begin{abstract}
In the paper the analysis of water supply infrastructure in Lublin Province was presented. We analysed the length of the water supply system divided into urban and rural areas, also change of water supply system growth and the analysis of number of connections to buildings over the studied years were presented. An issue of water consumption for household purposes, for industry, agriculture and forestry, and the operational needs of the water supply network, was also discussed. We analysed the percentage of the population using the water supply system and the indicators of equipping individual cities and counties in water supply systems were shown. The paper presents the analysis of the density of the water supply system in relation to national conditions. Appointed indicator of failure rate of water supply systems in the individual districts of Lublin province has an average reliability and failure rate according to the criteria recommended in the study [7]. There was a steady increase in the water supply system and related to it increase in investments. Significant changes that occurred in the field of water supply were the result of Polish accession to the European Union. After this accession Poland had to meet certain requirements related to the functioning of environment protection infrastructure. Changes in individual parameters characterizing the water supply infrastructure fit with the national tendency.
\end{abstract}

Keywords: water supply, development of the water supply infrastructure, density of water supply network, increase of water supply network

\section{Introduction}

The Lublin province covers an area of 25,000 square kilometres and takes the third place in the country. The region is inhabited by 2151000 people, it covers about six percent of the country. Province is located in the south-eastern Poland and borders with Belarus by Brest circuit and Ukraine by Lvov and Volyn circuits.

\footnotetext{
${ }^{1}$ Autor do korespondencji / corresponding author: Katarzyna Pietrucha-Urbanik, Politechnika Rzeszowska, al. Powstańców Warszawy 6, 35-959 Rzeszów, tel. 17 8651703, kpiet@prz.edu.pl

2 Tatiana Chryń, Politechnika Rzeszowska
} 
The Lublin province has low population density, amounted to $86 \mathrm{inh} \cdot \mathrm{km}-2$ in 2013, which in a scale of the country locates it in the 12th place. The population in the last decade decreased by three percent and the natural increase over the studied years is negative, as a result of high immigration and the fact that this region is poorly industrialized. Poor industrialization causes that half of the region's population live in rural areas. The considered province is divided into 4 city counties, 20 counties and 213 municipalities, including 41 towns and 4116 villages [4].

The individual parameters associated with the state of the water supply are subjected to constant changes, some remain at a steady level or show a downward or growing trend. Analysis of the development of rural and urban areas in Poland due to the changes in the field of water supply is the subject of many studies $[1-3,5,6]$. Significant changes that occurred in this area were the result of Polish accession to the European Union, as a result of which the country had to meet certain requirements related to the functioning of water supply infrastructure. Polish accession to the EU structures resulted in a significant increase in funding, which undoubtedly contributed to the development of water supply infrastructure. Also performed failure analysis constitute the important step in proper management of the water supply network [7-12].

The aim of this study is to analyse the infrastructure of water supply made on the basis of statistical yearbooks compiled by the Central Statistical Office for the province for the years 1998-2013 and for the chosen parameters of analysis for 2015 [4].

\section{Water consumption}

Water sale in the cities of the Lublin province in the last year of analysis amounted to $84400 \mathrm{~m}^{3}$, which represents about 7,5\% of water sales in the country. The largest water sale took place in Lublin $\left(43,4 \mathrm{dam}^{3}\right)$, then at a similar level of about $6 \mathrm{dam}^{3}$ are the following cities: Zamosc, Pulawy, Biala Podlaska and Chelm. Low water sale occurred in the Frampol and Tyszowce $\left(0,1 \mathrm{dam}^{3}\right)$. The large discrepancy between Lublin and other cities is due to the fact that Lublin is the biggest city in the region, therefore it has the largest number of inhabitants and the largest demand for water. The water price for $\mathrm{m}^{3}$ in the Lublin province for 8 years increased by $0,81 \mathrm{zl}$ and amounted to $2,76 \mathrm{zl}$ in 2013 . At the same time this price is $23 \%$ lower than the average price per $\mathrm{m} 3$ of water in Poland.

Average daily water consumption in the region amounted to $75 \mathrm{dm}^{3} \cdot \mathrm{d}^{-1} \cdot \mathrm{inh}^{-1}$, which is more than the average for the whole Poland by about $11 \mathrm{dm}^{3}$. The lowest water consumption was recorded in the districts of Chelm $\left(52 \mathrm{dm}^{3} \cdot \mathrm{d}^{-1} \cdot \mathrm{inh}^{-1}\right)$, Hrubieszow $\left(51 \mathrm{dm}^{3} \cdot \mathrm{d}^{-1} \cdot \mathrm{inh}^{-1}\right)$ and Zamosc $\left(42 \mathrm{dm}^{3} \cdot \mathrm{d}^{-1} \cdot \mathrm{inh}^{-1}\right)$.

Water consumption in the various districts of the Lublin province is shown in Figure 1. 


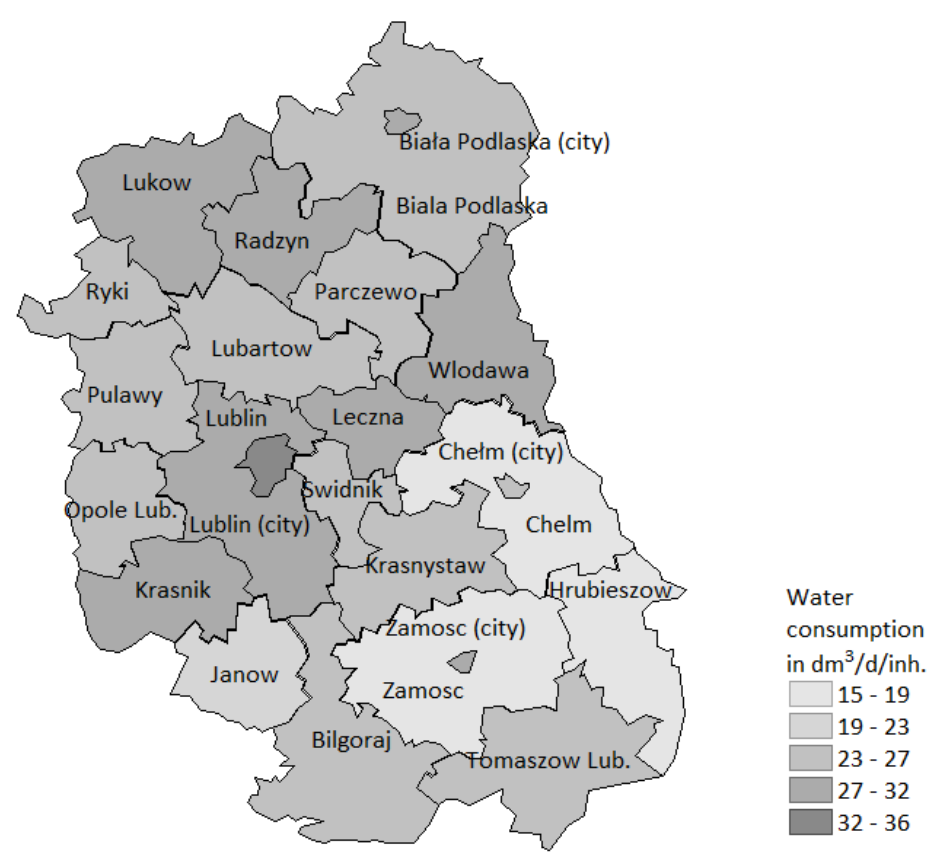

Fig. 1. Water consumption in the various districts of the Lublin province

Rys. 1. Zużycie wody w poszczególnych powiatach województwie lubelskim

In the last year of the analysis the inhabitants of the region consumed for living purposes $35 \%$ more water than in 1998, which resulted primarily from the expansion of the existing water supply network and connection of the new customers to the public water network. Undoubtedly, the same trend in water consumption through years is influenced by reducing losses in water distribution, installation of water meters, as well as the increase of the water price, which contributes to saving. Also commercialization of fees for water was the main instrument of limiting water consumption.

Water consumption for the industry in the Lublin province in 2008-2010 showed a downward trend, in other years remained at a comparable level. The percentage share of industry in the overall consumption of water in the Lublin province during the considered period of time was, on average, $32 \%$. In the last year of the analysis water consumption for industry amounted to $140000 \mathrm{dam}^{3}$. Analysing the amount of water taken and consumed for the agriculture and forestry in the period of 16 years it should be stated that it remained at similar level, amounting, in last year of the analysis, to about $47 \%$ of the overall water consumption $\left(180000 \mathrm{dam}^{3}\right)$. On the other hand, water consumption for the purposes of exploitation amounted to $70000 \mathrm{dam}^{3}$. Lower water consumption occurred in rural areas, which was due to the fact that in the cities the water supply network is constantly expanding and larger amounts of water are used for technological purposes, such as, for example, washing the filters. 


\section{Analysis of changes in the length of the water supply network}

The Lublin province is clearly differentiated in terms of the access to the network technical infrastructure considering urban and rural areas. In the years 1998-2013 the increase of the water supply network was $65 \%$, which means that in the Lublin province the development of water supply infrastructure can be assessed in positive way, in comparison to the average growth in whole Poland, amounted to $34 \%$. The largest increase of the water supply network in the Lublin province was recorded in 2000, while the lowest in 2002. Within fifteen years of the analysis the average increase in the network was $540 \mathrm{~km}$. Compared to other regions it can be assumed that the Lublin province is close to the average growth of water supply infrastructure. The most developing province is Masovian where the water supply system increased in 2013 by $26 \%$ compared to 2005 .

In the Figures 2 and 3 the increase in the water supply system in cities and rural areas in the Lublin province was shown.

The length of the water supply system in urban areas during the considered period increased by $420,2 \mathrm{~km}$, which constituted $3,19 \%$ of the increase of the national network. The biggest difference compared to the previous year occurred in 2007 and was $46 \mathrm{~km}$, the smallest length of the network in cities was built in 2011, only $19 \mathrm{~km}$. The average increase of water supply network in the Lublin province is $28 \mathrm{~km}$ per year.

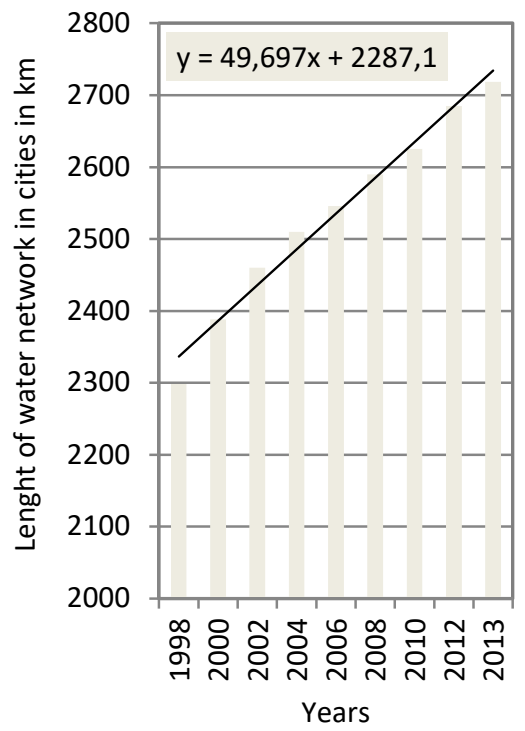

Fig. 2. Increase in the length of the water supply network in cities in the Lublin province

Rys. 2. Wzrost długości sieci wodociągowej w województwie lubelskim w miastach

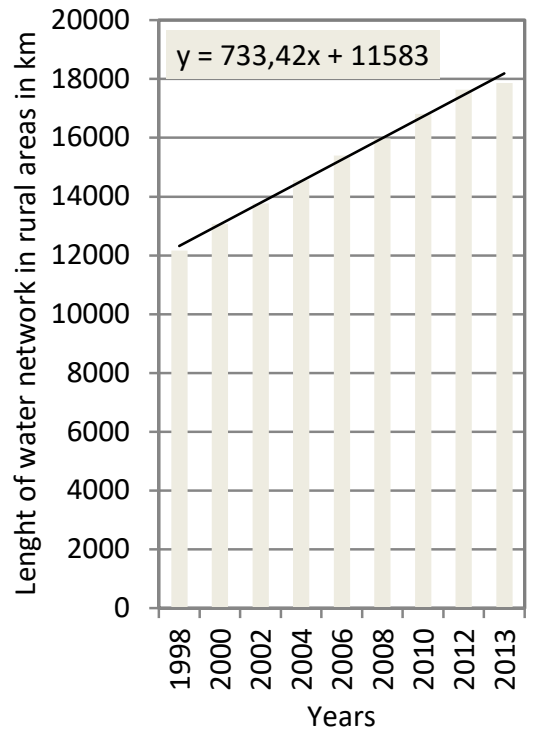

Fig. 3. Increase in the length of the water supply network in rural areas in the Lublin province

Rys. 3. Wzrost długości sieci wodociągowej w województwie lubelskim w miastach 
It can be noticed that the increase of the water supply system at the analysed time was linear and systematic, the greatest length of the network occurred in the city of Lublin, with the amount of $51,4 \mathrm{~km}$, and the smallest in Zamosc, about 40,2 km.

The detailed analysis showed that in the cities with less than 10000 inhabitants (21 cities), the average length of the network was $27,7 \mathrm{~km}$, in the cities with 10 to 20 thousand inhabitants (10 cities) the average length was $51.8 \mathrm{~km}$, in the cities with 20 to 50 thousand inhabitants about $84.6 \mathrm{~km}$ and in the cities with 50 to 100 thousand inhabitants about 165.5 kilometres.

Taking into account the rural areas during the considered period the length of water supply system has increased by $5700 \mathrm{~km}$ (Fig. 2). The average annual increase of the water supply network length was $380 \mathrm{~km}$, while in the whole country it amounted to $4849 \mathrm{~km}$.

In the Lublin province in the analysed period 50018 new connections were made, the average number of connections to the water supply system amounted to 3335 per year The largest number of new connections was made in 2008 and amounted to 8584 .

With the increase of the water supply network length and thus a greater availability of water services, the number of street standposts decreased from 979 to 553, an identical downward trend was maintained in the country, where the number of street standposts decreased by $30 \%$ of 6547 . A similar situation occurred in the rural areas of the Lublin province, in the cities the number of street standposts decreased from 570 to 278 and in the urban areas the number of street standposts decreased from 409 to 275 .

\section{Density of the water supply network}

In the analysed period the density of the water supply network in the Lublin province has increased from 69,6 to $81,9 \mathrm{~km} \cdot 100 \mathrm{~km}^{-2}$, while the average density of the country ranged from 78,6 to $92,0 \mathrm{~km} \cdot 100 \mathrm{~km}^{-2}$. Taking into account all the provinces, the largest density of the water supply system occurred in the Kuyavian Pomeranian province and amounted to $126,5 \mathrm{~km} \cdot 100 \mathrm{~km}^{-2}$. The lowest density was in West Pomeranian, $46.4 \mathrm{~km} \cdot 100 \mathrm{~km}^{-2}$. The Lublin province with a density of $81,9 \mathrm{~km} \cdot 100 \mathrm{~km}^{-2}$ is in 8 th position among all the provinces in terms of the development of water supply infrastructure. Of course it should be remembered that cities because of their construction are more dense and have smaller surface area and thus the water supply network is denser and longer than in rural areas. Discussed dependence is shown in Figures 4 and 5. 


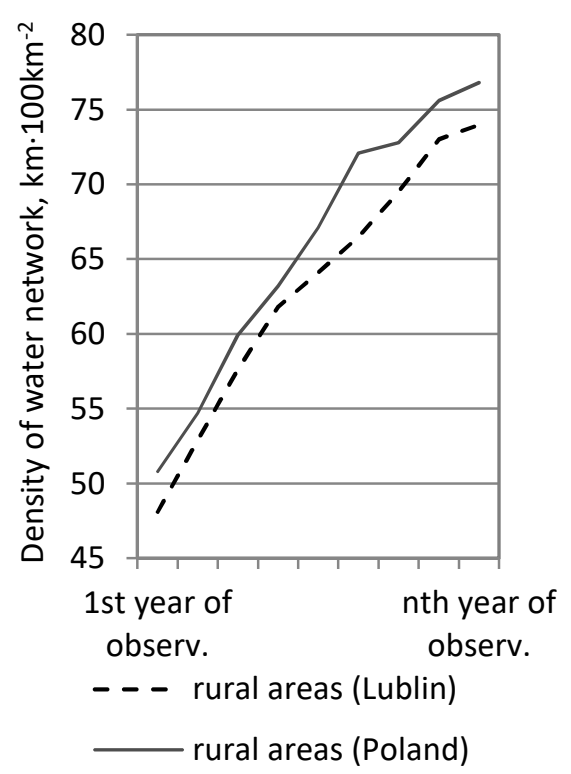

Fig. 4. Density of the water supply network in the rural areas in the districts of Lublin province

Rys. 4. Gęstość sieci wodociągowej na obszarach wiejskich województwa lubelskiego

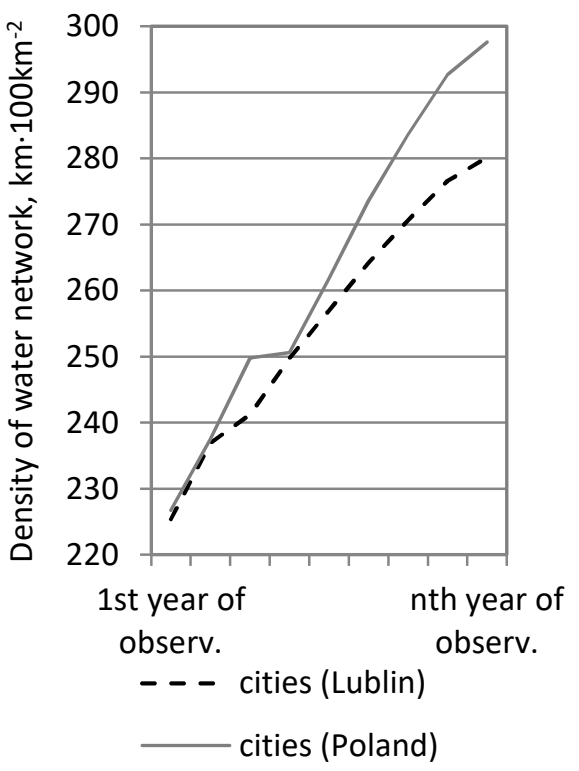

Fig. 5. Density of the water supply network in the cities in the districts of Lublin province

Rys. 5. Gęstość sieci wodociągowej w miastach województwa lubelskiego

In Poland, the average density of the urban water supply network in 2013 was $297,6 \mathrm{~km} \cdot 100 \mathrm{~km}^{-2}$ and increased in the analysed period by $39,8 \mathrm{~km} \cdot 100 \mathrm{~km}^{-2}$. The greatest density of water supply system in the city in 2013 had the Greater Poland province $\left(397,5 \mathrm{~km} \cdot 100 \mathrm{~km}^{-2}\right)$, while the lowest had the Opole province $\left(200,5 \mathrm{~km} \cdot 100 \mathrm{~km}^{-2}\right)$.

The Lublin province in 2013 reached a density of $280,1 \mathrm{~km} \cdot 100 \mathrm{~km}^{-2}$, which means that during the nine years it increased by $29,5 \mathrm{~km} \cdot 100 \mathrm{~km}^{-2}$, an increase of $15,4 \%$. The largest cities of the province have the following density of the water supply network: Biala Podlaska $\left(355,3 \mathrm{~km} \cdot 100 \mathrm{~km}^{-2}\right)$, Chelm $\left(499,1 \mathrm{~km} \cdot 100 \mathrm{~km}^{-2}\right)$, Zamosc $\left(451,1 \mathrm{~km} \cdot 100 \mathrm{~km}^{-2}\right)$, Lublin $\left(395,9 \mathrm{~km} \cdot 100 \mathrm{~km}^{-2}\right)$.

On the other hand, in Poland, the average density of rural water supply network in 2013 amounted to $76,8 \mathrm{~km} \cdot 100 \mathrm{~km}^{-2}$ and increased in the analysed period by $11,3 \mathrm{~km} \cdot 100 \mathrm{~km}^{-2}$. The greatest density of water supply in rural areas in 2013 had the Kuyavian Pomeranian $\left(114,3 \mathrm{~km} \cdot 100 \mathrm{~km}^{-2}\right)$, while the lowest the West Pomeranian and Lubusz $\left(35 \mathrm{~km} \cdot 100 \mathrm{~km}^{-2}\right)$. Rural areas in the Lublin province in 2013 reached a density of $74 \mathrm{~km} \cdot 100 \mathrm{~km}^{-2}$, which means that in 16 years it increased by $29,5 \mathrm{~km} \cdot 100 \mathrm{~km}^{-2}$, an increase of $38,5 \%$.

The greatest density of water supply network in rural areas were in such districts: Pulawy $\left(100,5 \mathrm{~km} \cdot 100 \quad \mathrm{~km}^{-2}\right)$, Lubartow $\left(90,7 \mathrm{~km} \cdot 100 \mathrm{~km}^{-2}\right)$, Krasnystaw $\left(84,9 \mathrm{~km} \cdot 100 \mathrm{~km}^{-2}\right)$ and Radzyn $\left(88,4 \mathrm{~km} \cdot 100 \mathrm{~km}^{-2}\right)$. Thanks to the 
means of financing the extension of water supply system takes place and thus the density of the water supply network increases. Undoubtedly, increasing the length of the water supply system in rural areas is a sign of their vast modernization and socio-economic development.

\section{The financial expenditure incurred on the construction of wa- ter supply infrastructure}

In the Lublin province since 1998 the systematic increase of expenditures on fixed assets for the construction of intakes and water supply is observed - to the level of 69 million zl in 2013. Expenditures on fixed assets for the construction and modernization of the water treatment plants amounted to more than 13 million zl and were significantly higher than in 2012. The largest expenditures incurred in 2013 in the districts of Pulawy and Biala Podlaska. They accounted to $7,08 \%$ of the total expenditures for the construction of intakes and water supply. Funds allocated to this type of investment are shown in Figure 6.

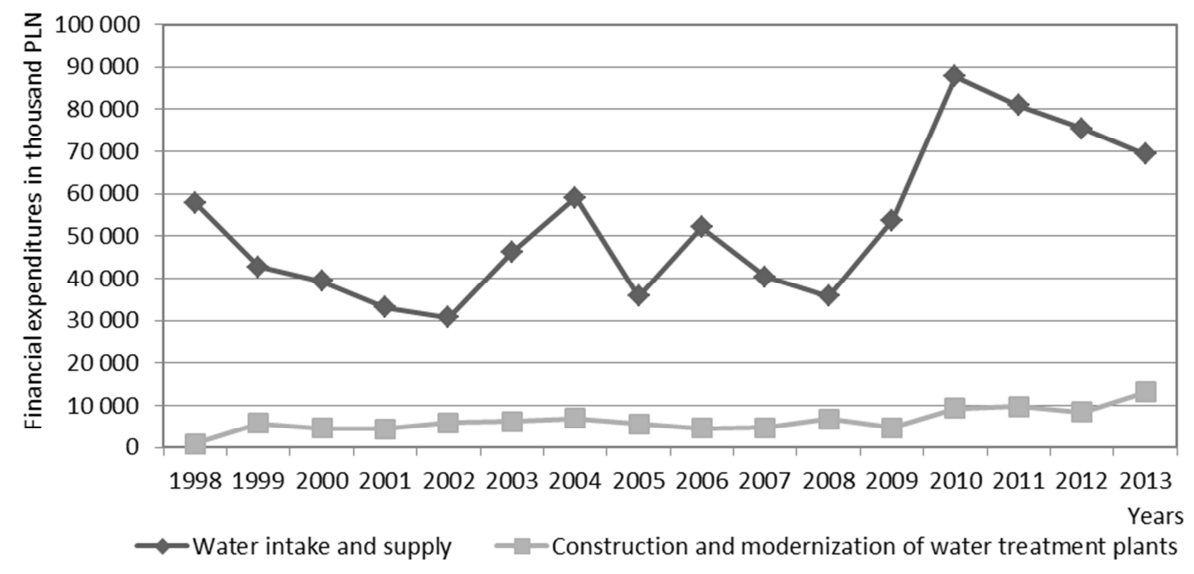

Fig. 6. Fixed assets for the construction and modernization of water supply infrastructure

Rys. 6. Środki trwałe przeznaczone na budowę oraz modernizację infrastruktury wodociągowej

Almost half of all the investment assigned to water management was related to new intakes and water supply infrastructure, as well as the modernization of the water intakes.

\section{Population using the water supply system}

In the last year of the analysis the overall percentage of the population using the water supply network was approx. $82 \%$, in the cities the access to water supply was $94 \%$ (in national scale in the cities this value was 95\%) and in rural are- 
as $72 \%$ (in national scale in rural areas it was $77 \%$ ). Since 1998, there was an increase of people using the water supply system in the cities by $10 \%$, while in case of rural areas by $16 \%$.

The largest availability of water supply system in the remaining provinces was: Opole - 94,6\%, West Pomeranian - 93,7\%, Silesia - 93,6\%, Pomeranian 93,1\% and Great Poland - 93,1\%. Taking into account the development of the water supply system in the whole country, an increase of the population using the water supply during considered period was $4 \%$, while in the Lublin province, this indicator increased by $7 \%$.

The degree of equipping individual districts with water supply systems is shown in Figure 7.

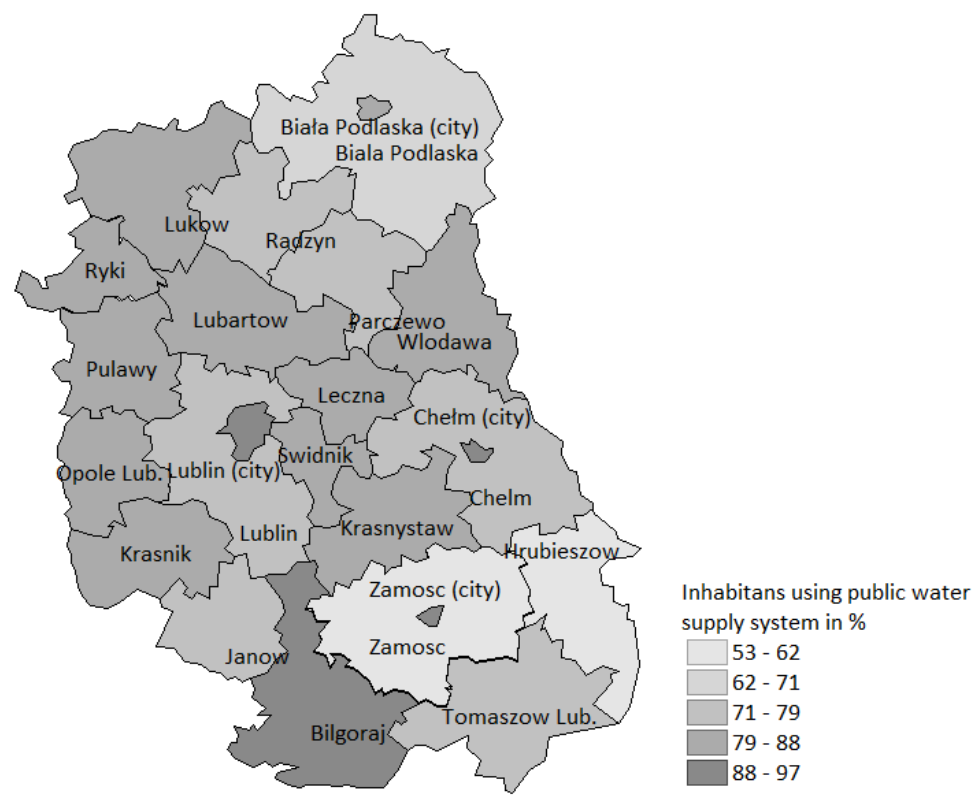

Fig. 7. The indicator of equipping individual districts in the Lublin province with water supply systems

Rys. 7. Wskaźnik zwodociągowania poszczególnych powiatów w województwie lubelskim

The highest level - 91,1\% - of the use of the water supply is in the county Bilgoraj. The lowest indicator is in Hrubieszow district (59\%), but in this county there was the greatest increase in the number of users of the water supply system in the last ten years. The detailed analysis showed that the highest degree of equipping with water supply systems in 2013 had the city of Leczna and it amounted to $99,1 \%$. The lowest degree was in the city of Biala Podlaska, only $86 \%$. 


\section{Failure rate of the water network}

To evaluate the technical condition of the water network the indicator of failure rate is used, which is calculated as the quotient of the number of failures in relation to the network length within one year [9].

The failure rates of the water supply network in the various districts of the Lublin province for obtained data, including water distribution network, were presented in Figure 8.

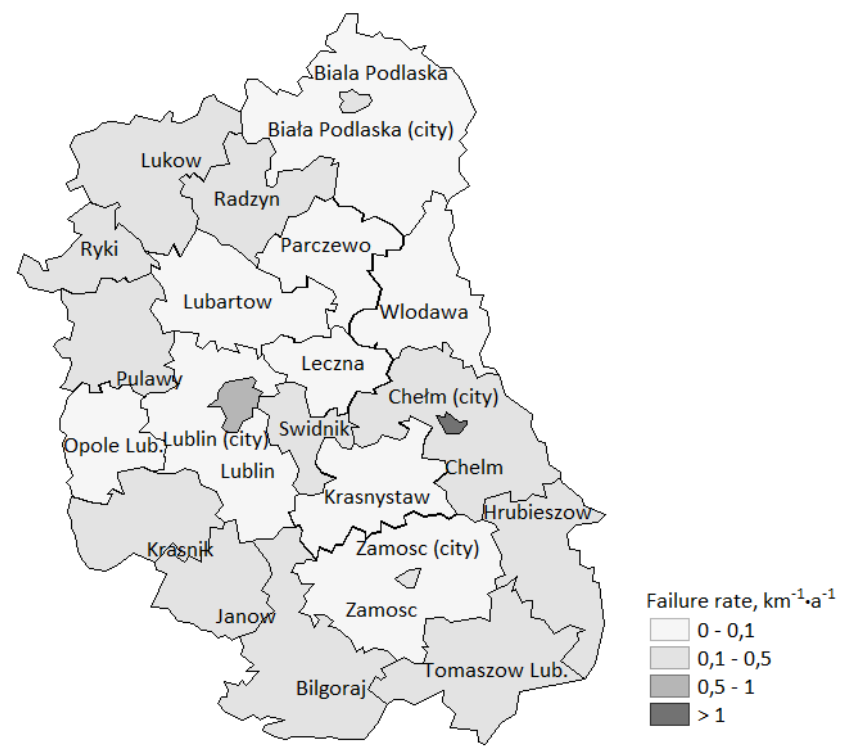

Fig. 8. The failure rates in different districts in the Lublin province

Rys. 8. Intensywność uszkodzeń w poszczególnych powiatach województwa lubelskiego

Criteria values of failure rate of water supply network were given in the paper [9]. Low failure rate is identified with the failure rate of less than $0,1 \mathrm{~km}^{-1} \cdot \mathrm{a}^{-1}$, the average failure rate means the failure rate from 0,1 to $0,5 \mathrm{~km}^{-1} \cdot \mathrm{a}^{-1}$, and the high failure rate is higher than 1 . The average failure rate determined for the whole province was $0,21 \mathrm{~km}^{-1} \cdot \mathrm{a}^{-1}$, which classifies the water supply network of the region as the average reliability.

The detailed analysis showed that in $42 \%$ of districts the water supply systems have low failure rate, while $8 \%$ are the water supply systems with high failure rate, so it can be concluded that the examined water supply networks are in good technical condition. 


\section{The degree of equipping with water supply networks}

The degree of equipping with water supply networks is expressed, for example, by the length of the water supply network per one recipient. The length of the water supply network per one user of the public water supply systems in the individual districts is shown in Figures 9 and 10. The highest value of this indicator have Biała Podlaska and Chelm districts, 23,87 and 23,62 m per one recipient, respectively. The lowest value of this indicator have Swidnik and Pulawy districts, 9,35 and 9,67 m per one recipient, respectively.

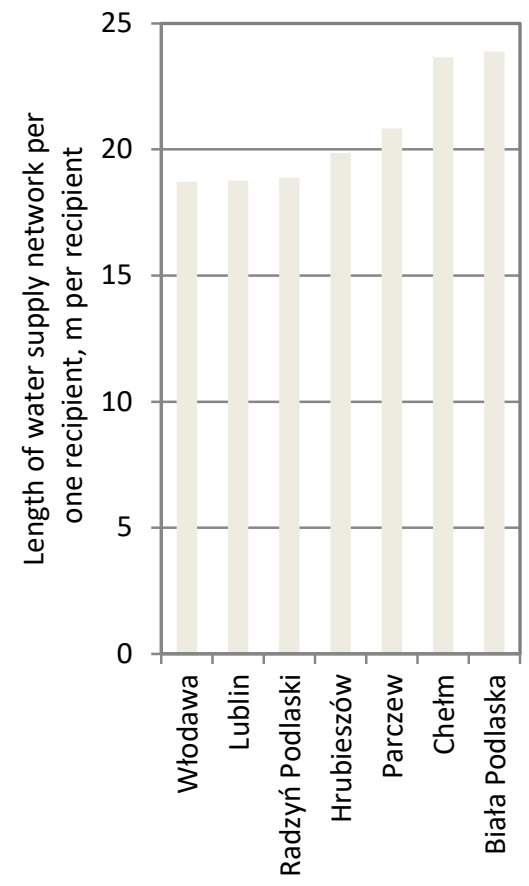

Fig. 9. The indicator of the greatest length of the water supply network per one recipient in the districts of Lublin province

Rys. 9. Wskaźnik z największą długością sieci wodociągowej przypadającą na 1 obsługiwanego $\mathrm{w}$ powiatach województwa lubelskiego

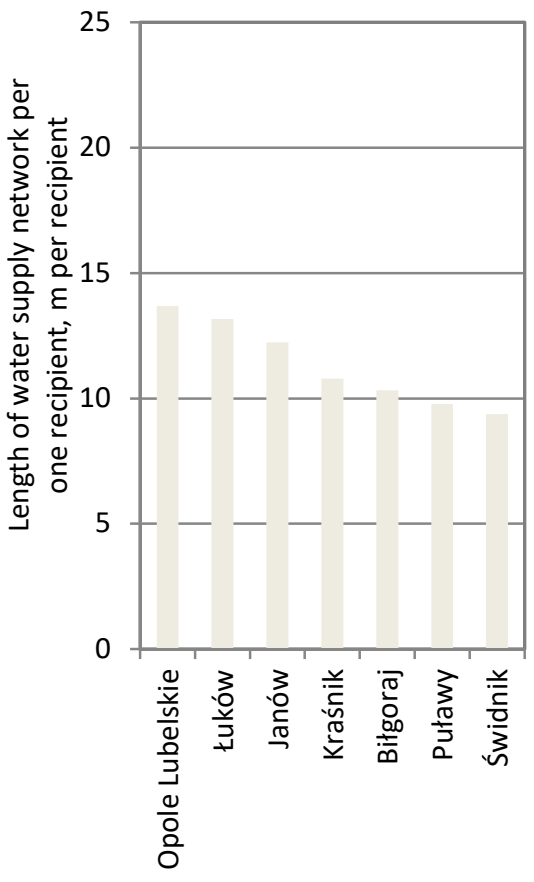

Fig. 10. The indicator of the smallest length of the water supply network per one recipient in the districts of Lublin province

Rys. 10. Wskaźnik z najmniejszą długości sieci wodociągową przypadającej na 1 obsługiwanego w powiatach województwa lubelskiego

The indicator of equipping with water supply network remains in close relation with the ratio of the use intensity of network equipment, defined as the ratio of annual water sale to the length of the water supply network [3]. The average daily water sale per $1 \mathrm{~km}$ of distribution network in the Lublin province is $7,28 \mathrm{~m}^{3} \cdot \mathrm{d}^{-1} \cdot \mathrm{km}^{-1}$. The usage rates of water supply network in the various districts of the province of Lublin are illustrated in Figures 9 and 10. 
The highest indicator have districts of Pulawy $\left(11,6 \mathrm{~m}^{3} \cdot \mathrm{d}^{-1} \cdot \mathrm{km}^{-1}\right)$, Swidnik $\left(10,1 \mathrm{~m}^{3} \cdot \mathrm{d}^{-1} \cdot \mathrm{km}^{-1}\right)$, Krasnik $\left(9,7 \mathrm{~m}^{3} \cdot \mathrm{d}^{-1} \cdot \mathrm{km}^{-1}\right)$, Lukow $\left(9,1 \mathrm{~m}^{3} \cdot \mathrm{d}^{-1} \cdot \mathrm{km}^{-1}\right)$, Bilgoraj $\left(8,4 \mathrm{~m}^{3} \cdot \mathrm{d}^{-1} \cdot \mathrm{km}^{-1}\right)$ and Ryki $\left(7,8 \mathrm{~m}^{3} \cdot \mathrm{d}^{-1} \cdot \mathrm{km}^{-1}\right)$. The lowest rate of equipping with the water supply systems is in districts of Chelm $\left(3,3 \mathrm{~m}^{3} \cdot \mathrm{d}^{-1} \cdot \mathrm{km}^{-1}\right)$, Biala Podlaska $\left(4,4 \mathrm{~m}^{3} \cdot \mathrm{d}^{-1} \cdot \mathrm{km}^{-1}\right)$, Hrubieszow $\left(4,7 \mathrm{~m}^{3} \cdot \mathrm{d}^{-1} \cdot \mathrm{km}^{-1}\right)$, Zamosc $\left(4,8 \mathrm{~m}^{3} \cdot \mathrm{d}^{-1} \cdot \mathrm{km}^{-1}\right)$ and Parczew $\left(4,9 \mathrm{~m}^{3} \cdot \mathrm{d}^{-1} \cdot \mathrm{km}^{-1}\right)$.

\section{Conclusion}

The performed analysis of water supply infrastructure confirmed the positive changes in its development, which undoubtedly was associated with an increase in the length of the water supply system, which in the Lublin province in the last fifteen years was $8089 \mathrm{~km}$, while in the cities about 420 kilometres. Also it is worth to note that only in the last six years in the Lublin province the level of the access to water supply system increased by almost $10 \%$, which now places this province in the seventh position in the country.

Also the positive changes have occurred in increasing the level of equipping the settlement units with water supply network and thus increasing the access to the water supply network to a level comparable with the level of the country. The development of municipal infrastructure, including water supply and, subsequently, sewerage, causes the desired economic effects, and, consequently, also social effects, so it is very important to undertake new investments to improve the functioning of the settlement units.

\section{Literature}

[1] Chudy W.: Wyposażenie polskich obszarów wiejskich w infrastrukturę komunalną, Infrastruktura I Ekologia Terenów Wiejskich, Nr 2/2007, s. 111-120.

[2] Dohnalik P., Jędrzejewski Z.: Efektywna eksploatacja wodociągów, ograniczenie strat wody, Wydawnictwo LEMTECH, Kraków 2004.

[3] Dymaczewski Z., Sozański M.M.: Wodociągi i kanalizacja w Polsce tradycja i współczesność, Polska Fundacja Ochrony Zasobów Wodnych, Poznań-Bydgoszcz 2002.

[4] Główny Urząd Statystyczny, Ochrona środowiska, Roczniki statystyczne za lata 1998-2015.

[5] Kłos-Trębakiewicz H., Osuch-Pajdzińska E., Wybrane wskaźniki charakteryzujące wodociągi w dużych miastach polskich w latach 2005-2008, Gaz, Woda, Technika Sanitarna, Nr 3/2010, s. 7-15.

[6] Korzeniowski P.: Zbiorowe zaopatrzenie w wodę i zbiorowe odprowadzanie ścieków, Wodociągi i Kanalizacja, Nr 7-8/2010, s. 18-19.

[7] Kwietniewski M., Awaryjność infrastruktury wodociągowej i kanalizacyjnej w Polsce w świetle badań eksploatacyjnych, XXV Konf. Naukowo-Techniczna, Międzyzdroje 2011, s. 128-129. 
[8] Kwietniewski M., Rak J., Niezawodność infrastruktury wodociągowej i kanalizacyjnej w Polsce, PAN, Warszawa 2010.

[9] Kwietniewski M., Roman M., Kłoss-Trębaczkiewicz H.: Niezawodność wodociągów i kanalizacji. Arkady, Warszawa 1993.

[10] Pietrucha-Urbanik K., Bernacka A.: Analysis of Water Infrastructure Development a Case Study of the Exemplary Water Supply System. Czasopismo Inżynierii Lądowej, Środowiska i Architektury, Journal of Civil Engineering, Environment and Architecture, JCEEA, z. 63, nr 2/I/2016, s. 221-230. DOI: 10.7862/rb.2016.124.

[11] Rak J.: Podstawy bezpieczeństwa systemów zaopatrzenia w wodę. Komitet Inżynierii Środowiska PAN. t. 28, 2005.

[12] Rak J.: Metoda planowania remontów sieci wodociągowej na przykładzie miasta krosna. Czasopismo Inżynierii Lądowej, Środowiska i Architektury, Journal of Civil Engineering, Environment and Architecture, JCEEA, z. 61, nr 1/2014, s. 225-232. DOI: $10.7862 /$ rb.2014.15.

\section{ANALIZA STANU INFRASTRUKTURY WODOCIĄGOWEJ W WOJEWÓDZTWIE LUBELSKIM}

\section{Streszczenie}

W pracy przedstawiono analizę infrastruktury wodociągowej w województwie lubelskim. Analizie poddano długość oraz gęstość sieci wodociągowej w podziale na tereny miejskie oraz wiejskie, zaprezentowano również zmianę przyrostu długości sieci wodociągowej oraz analizę liczby przyłączy prowadzących do budynków na przestrzeni badanych lat. Poruszono również kwestię zużycia wody na poszczególne cele gospodarczo-bytowe, potrzeby przemysłu, rolnictwa i leśnictwa oraz cele eksploatacyjne sieci wodociągowej. Przeanalizowano procent ludności korzystającej oraz pokazano wskaźniki zwodociągowania poszczególnych miast i powiatów. W pracy przedstawiono także analizę gęstości sieci wodociągowej w odniesieniu do warunków krajowych.

Wyznaczony wskaźnik intensywności uszkodzeń sieci wodociągowych w poszczególnych powiatach województwa lubelskiego charakteryzuje się średnią niezawodnością oraz awaryjnością według kryteriów zalecanych w opracowaniu [7]. Zaobserwowano systematyczny przyrost sieci wodociagowej oraz związany z tym wzrost nakładów inwestycyjnych. Znaczne zmiany, który zachodziły w zakresie zaopatrzenia w wodę były wynikiem akcesji Polski do Unii Europejskiej. Wskutek czego państwo polskie musiało spełnić określone wymagania związane z funkcjonowaniem infrastruktury służącej ochronie środowiska. Zmiany poszczególnych parametrów charakteryzujących infrastrukturę wodociągową wpisują się w tendencję krajową.

Słowa kluczowe: wodociągi, rozwój infrastruktury wodociągowej, gęstość sieci wodociągowej, przyrost sieci wodociągowej

DOI:10.7862/rb.2016.216

Przestano do redakcji: $30.09 .2016 r$.

Przyjęto do druku: 30.11.2016 r. 